30 Pliny, The History of the World, Commonly Called the Natural History of C. Plinius Secundus, or Pliny, Translated by Philemon Holland, ed. Paul Turner (New York, 1964), 312-13. While more concerned with the Americas than Asia and the Mediterranean, Jeffrey Knapp's An Empire Nowhere: England, America, and Literature from Utopia to The Tempest (Berkeley, 1992) analyzes the centrality of England's remoteness and detachment to the geographic invention of early modern writers, in whose hands 'England's otherness could, then, be construed either as barbarous or as heavenly' (65). See also John Gilles, Shakespeare and the Geography of Difference (Cambridge, 1994), 31.

\title{
Guy of Warwick, Godfrey of Bouillon, and Elizabethan Repertory
}

Marlowe's Tamburlaine had a pervasive influence on the early modern stage and in particular on those plays grouped under the flexible generic label 'Turk plays'. This influence has been discussed at length, and discussion frequently focuses upon core texts, including early examples such as Robert Greene's Selimus and Alphonsus, King of Aragon, Peele's The Battle of Alcazar, Kyd's Soliman and Perseda, and later examples such as Shakespeare's Othello, Robert Daborne's A Christian Turn'd Turk, and Massinger's The Renegado. ${ }^{1}$ In this essay, however, I discuss the anonymous play The Tragical History, Admirable Atchievments and various events of Guy earl of Warwick and Thomas Heywood's The Four Prentices of London. These two plays can also be situated within the parameters of 'Turk plays' but have received much less critical attention in this context. Part of the reason for this neglect is that the dates and performance histories for both plays are sketchy or nonexistent. The dates of publication for both plays are not contemporaneous with the dates for their initial performances in the theatre: while The Tragical History was published in 1661 and The Four Prentices in 1615, critics have suggested that both plays are Elizabethan and were written for performance during the 1590 s. $^{2}$ Part of the support for such dating of the plays stems from the traces of Marlovian influence apparent in both, not only regarding verse style and interest in stage spectacle, but also in the ways both plays draw on the theatre's interest in and depiction of Islamic powers, either Turkish or Persian. To capitalize on the success of Marlowe's play and others like it, dramatists such as Heywood and the author of The Tragical History turned to medieval history and romance narratives for heroes whose stories they could dramatize. The 
careers of both Guy of Warwick and Godfrey of Bouillon involve a crusade or pilgrimage to the holy land and violent encounters with Saracen forces in Jerusalem. The Elizabethan dramatization of these two stories creates a palimpsest as English conceptions of Anglo-Ottoman relations in the sixteenth century are superimposed on the medieval depiction of English or European crusaders and their Saracen enemies. In this essay I argue that this palimpsestic effect is revealing in a number of ways. First, the adaptation of the story of Guy of Warwick for the stage permits insights into the repertorial strategies employed by dramatists and theatre companies as they strove to satisfy audience demand. Second, the apparently simplistic depictions of Anglo-Islamic relations in both The Tragical History and The Four Prentices of London, far from just providing examples of authorial immaturity (the play is thought to be Heywood's first), actually serve to point up the gap between the clear binarisms presented in each of the plays and the more complex and unsettling relationship between England and the Ottoman empire in the final decades of Elizabeth's reign.

The story of Guy of Warwick, the legendary English hero, was a familiar one during the early modern period. His feats of bravery were recorded in ballads and chapbooks, and were also the subject of a number of plays. ${ }^{3}$ Although the story developed over time, the narrative retained a number of key features and characters. Guy is the son of the steward of the Earl of Warwick, who falls in love with the earl's daughter Felice. When Felice rejects Guy he embarks on a series of adventures to prove himself as a knight. When Guy returns to England Felice agrees to marry him. Shortly afterward Guy embarks on a pilgrimage to Jerusalem to atone for his violent and sinful life. During his time in the holy land Guy fights and kills a Saracen giant called Amarant. When Guy returns home he is called upon by the king to defend England against the Danes. He fights and defeats a Danish giant called Colbrand. He then retires to Warwick to live as a hermit and later dies having been reunited with Felice. ${ }^{4}$ The romance narrative telescopes the historical period of the tenth and eleventh centuries as it brings together figures such as Athelstone, King of England and the King of Jerusalem, together with a Middle Eastern backdrop which is peopled by Saracens. In The Tragical History, however, the play world conflates Saracens and pagans with sixteenth-century European conceptions of Ottoman sultans and Turks. Sultan Shamurath, as I shall argue, is inserted into a romance world which is traditionally occupied by Saracens, the traditional enemies found within crusade narratives. Guy's exploits are recorded in a number of contemporary accounts of his 
life, including the ballad 'A pleasant song of the Valiant Deeds of Chivalry, atchieved by the Noble Knight, Sir Guy of Warwick' which summarizes his encounters with the Saracen, giant, and other pagan enemies in the following stanza:

\author{
I slew a Giant Amarant \\ In battel fiercely hand to hand \\ And doughty Barknard killed I \\ The mighty Duke of that same land. 5
}

Samuel Rowlands's poem The Famous History of Guy Earl of Warwick, entered in the Stationer's Register in 1608, went through a number of editions during the seventeenth century and included a woodcut of Guy fighting the giant Amarant (fig. 1). In the foreground of the image lie Guy's pilgrim hat and cloak which have been replaced by a suit of chain mail, while Amarant is naked to the waist and brandishes a spiked club. In the edition published in 1625 the woodcut is accompanied by the following lines:
A Gyant called Amarant
Guy valiantly destroyes:
Whereby wrong'd Ladyes, captive Knights,
Their libertie enjoyes. ${ }^{6}$

Critics of The Tragical History have remarked upon the ways in which the play bears traces of Marlovian influence. The dramatized story of Guy of Warwick certainly shares some of the structural and thematic features of Tamburlaine: both are episodic as each protagonist encounters and defeats a series of enemies, and both plays trace the careers of Guy and Tamburlaine as military supremos who are defeated only by death. Guy of Warwick's story in the theatre functions perhaps in a similar way to that of Tamburlaine since it would allow the audience to indulge in the fantasy of recalling and imagining English military successes of the past. Helen Cooper, for example, argues that its verse style suggests that the play can be dated to the early 1590s: 'Marlowe's mighty line is distinctly audible as an influence. The echoes sometimes emerge in concept or phrasing, sometimes in the use of exotic names or other polysyllables'. These features are noticeable in Guy's description of his success in the opening scene of the play: 
These kingly favours that your grace hath shown,

In honouring me a worthlesse Subject thus,

Hath plum'd my thoughts with Eagle-flighted wings,

And beares my mounting mind as high as Heaven. ${ }^{8}$

This speech echoes Tamburlaine's speech in Tamburlaine Part One when he explains to Cosroe what prompted him to seek the crown of Persia:

Nature, that framed us of four elements

Warring within our breasts for regiment,

Doth teach us to have aspiring minds:

Our souls, whose faculties can comprehend

The wondrous architecture of the world

And measure every wand'ring planet's course,

Still climbing after knowledge infinite

And always moving as the restless spheres,

Wills us to wear ourselves and never rest

Until we reach the ripest fruit of all,

That perfect bliss and sole felicity,

The sweet fruition of an earthly crown. ${ }^{9}$

Marlowe's distinctive verse style is particularly striking in the speeches of the Sultan Shamurath in the scenes involving the vaunting between the Ottoman emperor and the King of Jerusalem:

Know petty king of fair Jerusalem

I am the mighty Sultan Shamurath

That rules the tripple city Babylon

And all the kingdomes of the Eastern world.

Velma Bourgeois Richmond also discusses the ways in which the influence extends to stage spectacle and characterization: 'Sultan Shamurath parleys with the King of Jerusalem "upon the walls"; there are alarums excursions. The eastern setting and vigorous claims are reminiscent of Marlowe's Tamburlaine..$^{10}$ The siege of Jerusalem depicted in The Tragical History permits stage action which replicates comparable scenes from Tamburlaine Part Two as the stage directions describe: 'A parley sounded, Enter the King of Jerusalem upon the wall's. This recalls the most famous example of this scenario at the 


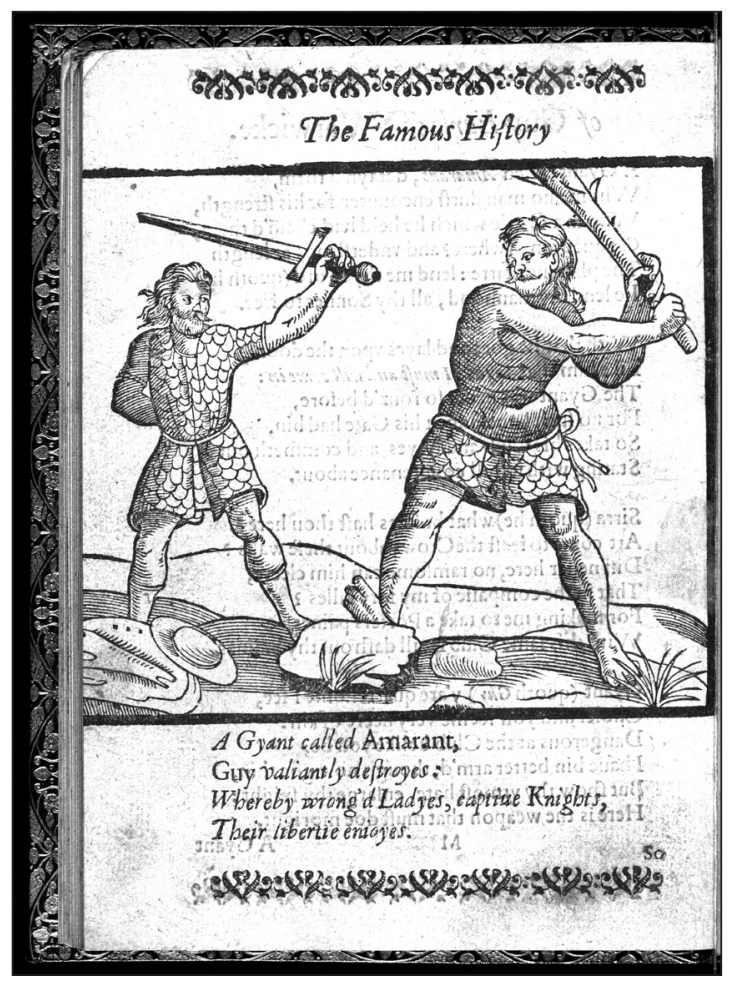

Fig. 1. Guy fights the giant Amarant. From Samuel Rowland's The Famous History of Guy Earl or Warwick (London: E. Allde, 1625), sig. M1v. Houghton Library, Harvard University. STC 21378.7

opening of Act 5: 'Enter the GOVERNOR OF BABYLON upon the walls with [MAXIMUS and] others' (5.1.0. sd). The governor refuses to agree to a truce and the town is taken; Tamburlaine then orders that he be 'Hang[ed] ... in chains upon the city walls / And let my soldiers shoot the slave to death' (5.1.108-9). The stage directions summarize the battle and subsequent defeat of the Turks: 'Alarum excursions. Enter Sultan and Zorastes flying, Guy and they fight, Zorastes escapeth, Guy taketh Sultan Prisoner. Then enter the King of Jerusalem'. Guy hands the Sultan over to the King of Jerusalem who in turn suggests that Guy should have the Sultan as an opportunity to secure a ransom. The Sultan is keen to be ransomed and promises to return towns and cities in the Middle East to Christian control, but Guy refuses to agree to these terms: 


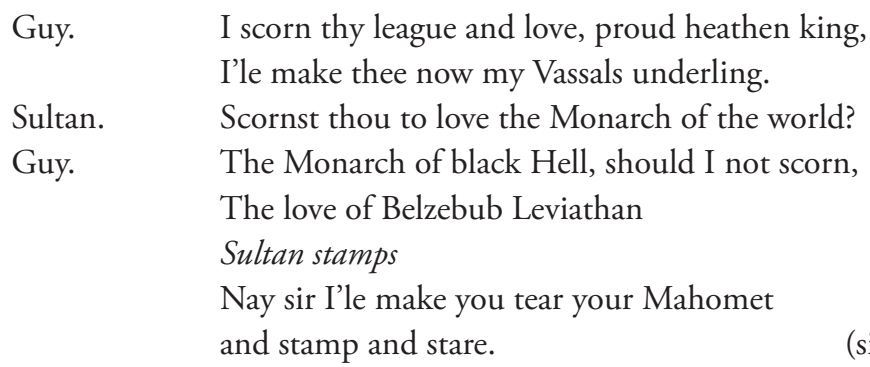

Shamurath's pride and his behaviour recall that of Bajazeth in Tamburlaine Part One when Bajazeth refuses to eat the morsels of meat from Tamburlaine's sword: 'He takes it and stamps upon it'.

Guy's story of a quest that involves travelling to Jerusalem and violent encounters with Muslim forces certainly chimes with the issues and motifs which featured in Elizabethan 'Turk' plays such as Tamburlaine Parts One and Two, The Jew of Malta, The Battle of Alcazar, and The Famous History of Thomas Stukeley. Roslyn L. Knutson has argued that Elizabethan theatre companies used their repertories to market their most successful playing by staging revivals of their older plays such as Marlowe's Tamburlaine and by commissioning new plays which would complement their existing stock by replicating their most popular features. ${ }^{11}$ The figure of Shamurath in The Tragical History is a case in point. As suggested earlier, different accounts of Guy's story all describe Guy's pilgrimage to Jerusalem and report that whilst he is there he fights and kills a Saracen giant called Amarant. The Tragical History condenses events from Guy's career, using a Presenter at the start of each act to summarize the action and indicate shifts in time. The play also makes specific changes to the narrative. During Guy's journey to Jerusalem the play replaces the Saracen giant Amarant with a Turkish Sultan Shamurath and his diabolical counsellor Zorastes. The single combat between Amarant and Guy is replaced with a series of scenes in which Guy of Warwick helps to relieve the besieged city and defeat the Turks. Critics such as Cooper and R. S. Crane have each noted that some features of this dramatization of Guy's story are unique to the play and that these can be found in those scenes which bear the strongest signs of Marlovian influence. Crane argues, 'The remainder of the play, with the exception of the scenes at Jerusalem, was based upon the common source of nearly all the contemporary versions of the legend, the metrical romance'. ${ }^{12}$ 
The decision to replace the giant with a Turkish Sultan called Shamurath, I argue, was informed by the commercial pressures of the Elizabethan theatre where the plays in the repertories of different companies would seek to commission or adapt material to capitalize upon popular characters and motifs. In the case of the Turkish Sultan, Marlowe's Tamburlaine had provided the impetus for some of the plays which included Turkish characters, together with historical accounts of the Turks and the Ottoman Empire. The choice of the name Shamurath suggests that the dramatist selected a name which already had a theatrical pedigree since it is a variation on the following names: Amurath, Ameroth, and Amurack. Amurath, for example, was used for characters in Robert Greene's Selimus (1594) and Kyd's Soliman and Perseda (1592), and it is used as the name for the Turkish Sultan in George Peele's The Battle of Alcazar (1594). Amurack appears in Greene's The Comicall Historie of Alphonsus, King of Aragon (1599), whilst Ameroth is used in John of Bordeaux (1592). Matthew Dimmock has noted that whilst these names were popular on the stage, they were also used in contemporary writing as alternative names for Sultan Murad III, who ruled the Ottoman Empire from 1574 to 1595 and was the correspondent of Elizabeth I. ${ }^{13}$ Richard Hillman has argued that Shakespeare draws on his audience's familiarity with the dynastic manoeuvring of the Ottoman sultans, specifically the relationships between Amurath I and his son Bayezid and between Murad III and his son Mehmed III in the Henriad's references to the Turk. ${ }^{14}$ Hal's speech in 2 Henry IV is designed to reassure the nobles that his accession and reign will be smooth and untroubled:

This is the English, not the Turkish court;

Not Amurath an Amurath succeeds,

But Harry Harry. ${ }^{15}$

Hillman points out that the effect of this comparison is in fact to suggest parallels between the troubled father-son relationship of Henry IV with Prince $\mathrm{Hal}$ and similar father-son relationships within the Ottoman dynasty.

The name Shamurath in The Tragical History foregrounds the place of the play within a specific theatrical context, and the imitative qualities demonstrated by the character of the Sultan also highlight the metatheatrical nature of that role. The Tragical History therefore demonstrates some sophistication in its depiction of the Turk as a stage villain since it has its tongue firmly in its cheek. The sense in which the actor performing the part of Shamurath 
is role-playing a familiar part is also suggested by the irresistible comparison available to modern readers between the name Shamurath and that of Henry Fielding's parodic anti-heroine Shamela. Fielding created Shamela to satirize Samuel Richardson's exemplar of female virtue Pamela and here the parody works partly through Fielding's choice of name since the name Shamela underlines the novel's premise that the character is a fake Pamela and is shamming virtue. ${ }^{16}$ Whilst the aim of the author of The Tragical History was not the same kind of explicit parody used by Fielding, the name Shamurath does indicate an awareness of its self-reflexive quality.

Thomas Heywood's The Four Prentices London, with the Conquest of Jerusalem can also contribute to the discussion of The Tragical History as a product of the commercial forces of the Elizabethan theatre. In his dedication to the first published quarto in 1615 Heywood indicates that his play belonged to a previously popular genre and he offers a tantalizing suggestion about the date for the play when he remarks that it was written at the start of his career: 'That as Playes were then some fifteene or sixteene yeares agoe it was in the fashion'. ${ }^{17}$ These comments would suggest a performance date for the play around 1599 or 1600 if we are to take Heywood at his word. Critics have been divided over the dating of the play, mainly because Henslowe's Diary refers to several other plays, namely 'Jerusalem' which was performed in 1592 at the Rose by Lord Strange's Men and 'godfrey of bullen' in 1594-5 which was featured in the repertory of the Admiral's Men. ${ }^{18}$ Editors of The Four Prentices of London such as Mary Ann Weber Gasior have argued that the play described by Henslowe as '2 pte of godfrey of bullen' is in fact an early version of Heywood's play later published as The Four Prentices of London. ${ }^{19}$ Gasior argues that Henslowe marks the play 'ne' since it is a revision of the earlier play 'Jerusalem'. Other evidence supporting 1594 as the date for Heywood's play is an entry in the Stationers' Register on 19 June 1594 of 'an enterlude entituled Godfrey of Bulloigne with the conquest of Jerusalem', and although this playtext printed by John Danter has not survived it has been suggested that perhaps it is an early version of Heywood's play. ${ }^{20}$ The 1594 date also coincides with the publication of Richard Carew's translation that same year of the first five cantos of Tasso's Gerusalemme liberate, entitled Godfrey of Bulloigne, or, the recoverie of Hierusalem. ${ }^{21}$ Tasso's poem first appeared in England in 1581 and had influenced English poets including Spenser, who published the first three books of his epic The Faerie Queene in 1590 followed by Books IV-VI in 1596.22 The popularity of Godfrey's story may well have inspired Heywood to compose a play on this subject at this time. Carew's work was 
superseded by the complete translation of Gerusalemme liberata by Edward Fairfax in 1600, with extracts included in England's Parnassus published in the same year which would also coincide with Heywood's own dating of his play. ${ }^{23}$ The arguments advanced by Gaisor and earlier theatre historians such as W. W. Greg - namely that Heywood revised the play 'Jerusalem' and that the entries for 'godfrey of bullen' refer to The Four Prentices by a different title - have been challenged by Knutson's recent work. Knutson argues that the critical tradition of treating plays with titles suggesting the same or similar subject matter as different titles for the same play or revisions of a single play has the effect of glossing over the commercial practice of commissioning plays on similar or the same topics. ${ }^{24}$ Knutson also suggests that the development of the two-part play, comparable to the modern day film sequel, was another commercial strategy used by dramatists and that 'godfrey of bullen', like 'Hercules' and 'Tamar Cham', for example, was probably another instance of this principle at work. ${ }^{25}$

Like The Tragical History, The Four Prentices uses features from the life of a popular medieval hero to provide a thrilling adventure story that moves from London, across Europe to Jerusalem and back again. The Four Prentices dramatizes the historical figure of Godfrey of Bouillon who was the leader of the first crusade and the first Latin ruler of Palestine after the capture of Jerusalem in $1099 .{ }^{26}$ The play develops this premise to present the story of Godfrey and his three brothers and their decision to enlist as part of a crusade led by Robert, Duke of Normandy. Despite being the sons of the Duke of Bouillon, the brothers have been forced to work as apprentices in London when their father was banished from his lands by the King of France. The brothers are separated on their journey to Jerusalem when they become shipwrecked, and the play charts the adventures of Godfrey, Guy, Charles, and Eustace until they are reunited at Jerusalem and fight to defeat the Sophy of Persia and the Souldan of Babylon.

Godfrey of Bouillon, like Guy of Warwick, would have been a popular hero familiar to an Elizabethan theatre audience due to Godfrey's reputation as a Christian knight and his inclusion in the list of the Nine Worthies, a group of champions who exemplified the qualities found in great military leaders. The Nine Worthies were composed of three classical figures: Hector, Alexander the Great, and Julius Caesar; three biblical figures: David, Joshua, and Judas Maccabeus; and three Christian figures: Arthur, Charlemagne, and Godfrey of Bouillon. In some English Renaissance accounts of the Nine Worthies the figure of Godfrey of Bouillon was replaced by Guy of Warwick. 
Richard Lloyd's A brief Discourse of the Nine Worthies (1584), for example, includes Guy rather than Godfrey:

I am Guy the Barron bold, of the deed the doughtiest knight

That in my daies of England was, with shield or speare in fight.

An English man I am by birth, in faith a Christian true:

The wicked lawes of Infidels I utterlie eschue. ${ }^{27}$

The Four Prentices of London, like The Tragical History, also indicates its debt to Marlowe's Tamburlaine through its use of verse, characterization, and stage action. ${ }^{28}$ The massing of Christian and Muslim forces before the walls of Jerusalem provides an opportunity for vaunting between the Souldan and Robert, Duke of Normandy as each seeks to convey the scale of their armies using the evocative lists of locations favoured by Marlowe in Tamburlaine. The Souldan begins:

From Ganges to the Bay of Calecut,

From Turkey and the three-fold Arabie:

From Sauxin Eastward unto Nubia’s bounds,

From Lybia and the Land of Mauritans,

And from the red Sea to the wildernesse,

Have we unpeopled Kingdomes for these warres,

To be reveng'd on you base Christians. ${ }^{29}$

His claims are then countered by Robert who blends both the familiar and mythical names of England and other European locations:

From England, the best brood of martiall spirits,

Whose wals the Ocean washeth white as snow,

For which you strangers call it Albion:

From France, a Nation both renowned and fear'd,

From Scotland, Wales, even to the Irish Coast,

Beyond the pillars great Alcides rear'd,

At Gades in Spaine unto the Pyrene Hils,

Have we assembled men of dauntlesse spirits

To scourge you hence ye damned infidels.

(11. 2268-76) 
Although the Souldan is depicted as initially more mild-mannered than the Persian Sophy, both use the symbolic image of a red flag to signal their power in an effort to terrify their enemies. Turnus, the counsellor who supports the war-mongering of the Sophy and acts as ambassador to the Christians, recounts how

In Sion Towres hangs his victorius flagge,

Blowing defiance this way: and it showes

Like a red meteor in the troubled aire;

Or like a blazing comet, that foretels

The fall of Princes.

These references to a red flag allude to Tamburlaine's warning to the city of Damascus in Part One when he uses white, red, and black flags to indicate the fate of the town and its inhabitants:

But if he stay until the bloody flag

Be once advanc'd on my vermilion Tent,

He dies, and those that kept us out so long.

And when they see me march in black array

With mournfull streamers hanging down their heads,

Were in that citie all the world contain'd

Not one should scape: but perish by our swords.

The Souldan also hopes that the mere sight of the red flag will repel the advancing Christians:

Why swarme these Christians to our Citty wals?

Looke (forreiners) do not the lofty Spires,

And these cloud-kissing Turrets that you see,

Strike deadly terrour in your wounded soules?

Go, Persian, flourish my vermillion flag,

Advance my standard high, the sight whereof

Will drive these stragglers in disordered rankes,

And in a hurly burly throng them hence.

Whilst critics such as Mark Thornton Burnettt have discussed the relationship between Tamburlaine and The Four Prentices, earlier criticism has tended 
to regard the latter as the work of a fledgling dramatist, a play that does not demand serious consideration. Here critics appear to take their cue from the fact that The Four Apprentices was parodied in The Knight of the Burning Pestle. Swinburne describes Heywood's play as 'this Quixotic romance of the City, with its serio-comic ideal of crusading counter-jumpers' ${ }^{30}$ while Arthur Melville Clark describes it as:

an essay in the ranting Ercles vein of Greene... . In The Four Prentices Heywood transformed the Crusades from an account of epical struggles and an allegory, as Tasso meant it to be, of the life of man into a painted arras, a background with a picture of Jerusalem on it, for an amateur's dramatization of the symmetrical material of folk-literature. ${ }^{31}$

Frederick Boas acknowledges that while

The technique of the play is indeed immature, with its sprawling action and its use of a presenter and a dumb show ... it claims attention for it combines further sketches of city life with other features which were to appear in Heywood's plays, romantic adventures by sea and land and pseudo-history. 32

More recently critics have discussed the play in the context of early modern theatrical depictions of the Turk and the crusades. Nabil Matar argues that the representation of Muslims and Christians is simplistic as the Muslims appear 'bombastic and cruel' while the apprentices are martial heroes 'because they come from England'. ${ }^{3}$ The play makes explicit that the crusade has the support of Providence, a fact which absolves each of the apprentices of their murder of an Islamic king at the end of the play. The stage directions indicate the brutal stage action once the city of Jerusalem has fallen to the Christian forces: 'Alarum. The foure brethren each of them kill a Pagan King, take off their crownes, and exuent: two one way and two another' (sd 11. 2379). The killings and the campaign are divinely sanctioned according to Robert, Duke of Normandy:

Now smooth againe the wrinkles of your browes

And wash the bloud from off your hands in milke:

With penitentiall praises laud our God,

Ascribe all glory to the heavenly Powers,

Since Syon and Hierusalem are ours.

(11. 2380-4) 
The problem of how to deal with pagan prisoners and the difficult issues surrounding the subject of conversion are therefore averted.

Similar charges of simplicity could also be levelled at The Tragical History in its treatment of Anglo-Islamic relations. In this instance the issue of conversion is addressed, but is dealt with in such a way as to provide a European fantasy of Christianizing Islamic nations. The figure of Guy presents the double defeat of the imperial forces of the Sultan since he beats them on the battlefield and forces their conversion to Christianity. Shamurath, after some blustering when his demand to be ransomed is refused, agrees with remarkable alacrity to Guy's demand that he and his people convert to Christianity:

We yield consent victorious conqueror
The God you serve is great Omnipotent,
Ruling the day of battle as he please
Making one hundred kil ten thousand men
Such were the odds of our battallions
Therefore for Guy of Warwicks sake
Wee'l trust in Christ, and Mahound clean forsake.

(sig. C4r)

Time, the play's presenter, confirms that the conversion has taken place as he sums up the plot:

Time that in his ceaselesse motion

Controuls the hearts of Kings and Emperours

Hath now converted Sultan Samurath

To tread the Christian path of perfect Christendome

And now with bishops, priests and patriarcks

They are returned back to Babylon

To Christen all that heathen nation

Think this is done.

(sig. D1)

Although both plays present successful outcomes for each of the crusades and their respective heroes, the palimpsestic effect created in each through the adaptation of these medieval stories serves to underline the fictional quality of these play worlds, in stark contrast with the reality of more complex Anglo-Ottoman relations at the end of the sixteenth century. The apparently conservative handling of the Islamic characters in The Tragical History and The Four Prentices therefore has a subversive potential: rather than providing 
just an escapist fantasy, the plays encourage their audiences to be aware of the disjunction between the past and the present. The Tragical History and The Four Prentices can be grouped with those plays referred to as the 'Sons of Tamburlaine', ${ }^{34}$ but far from offering a didactic reduction of Marlowe's hero and the issues he raises, these deceptively 'simplistic' plays form part of a wider, sophisticated engagement with English conceptions of the 'Turk'.

Annaliese Connolly

\section{Notes}

1 For recent discussion of the complexities of representing 'the Turk' on the early modern stage see Nabil Matar, Turks, Moors, and Englishmen in the Age of Discovery (New York, 1999), Daniel J. Vitkus, Turning Turk: English Theater and the Multicultural Mediterranean, 1570-1630 (Houndmills, 2003), Jonathan Barton, Traffic and Turning: Islam and English Drama, 1579-1624 (Newark, 2005), Mark Hutchings, 'The "Turk Phenomenon" and the Repertory of the late Elizabethan Playhouse', Early Modern Literary Studies 16 (2007), 10.1-39 <http://purl.oclc.org/emls/si-16/hutcturk.htm>, and Brinda Charry, 'Turk Plays (1540-1660)', The Literary Encyclopedia, 25 August 2007.

2 See Helen Cooper, 'Did Shakespeare play the Clown?', TLS 5116 (20 April 2001), 26-7, John Peachman, 'Links Between Mucedorus and The Tragical History, Admirable Atchievments and Various Events of Guy Earl of Warwick', Notes and Queries (2006), 464-7, and Helen Cooper, 'Guy of Warwick, Upstart Crows and Mounting Sparrows', in Takashi Kozuka and J. R. Mulryne (eds), Shakespeare, Marlowe, Jonson: New Directions in Biography (Aldershot, 2006), 119-38. For the date of The Four Prentices see Samuel C. Chew, The Crescent and the Rose: Islam and the Renaissance (New York 1937), 97-8 and Thomas Heywood's The Four Prentice's of London: A Critical Old Spelling Edition, ed. Mary Ann Weber Gasior (New York, 1980), vii-xv.

3 See for example, Velma Bourgeois Richmond, The Legend of Guy of Warwick (New York, 1996).

4 See Richmond, The Legend of Guy of Warwick and Douglas Gray, 'Guy of Warwick (supp. fl. c. 930)', Oxford Dictionary of National Biography (Oxford, 2004) <http:// www.oxforddnb.com/view/article/11797>, accessed 6 January 2009. 
5 'A pleasant song of the Valiant Deeds of Chivalry, atchieved by the Noble Knight, Sir Guy of Warwick' (London, 1678; Wing: 2123.2:50-1).

6 Samuel Rowlands, The Famous History of Guy Earl of Warwick (London, 1625; sTC: $2^{\text {nd }}$ ed. 21378.7), sig. M1.

7 Cooper, 'Guy of Warwick', 125.

8 The Tragical History, Admirable Atchievments and various events of Guy earl of Warwick, (London, 1661), sig. A2r. All further quotations from the play will be taken from this edition and reference will be given in the text.

9 Christopher Marlowe, Tamburlaine the Great Parts One \& Two, ed. J. S. Cunningham (Manchester, 1999), 2.7.18-29. All further quotations from the play will be taken from this edition and reference will be given in the text.

10 Richmond, The Legend of Guy of Warwick, 206.

11 Roslyn L. Knutson, 'Marlowe Reruns: Repertorial Commerce and Marlowe's Plays in Revival', Sara Munson Deats and Robert A. Logan (eds), Marlowe's Empery: Expanding His Critical Contexts (London, 2002), 25-42.

12 Ronald S. Crane, 'The Vogue of Guy of Warwick from the Close of the Middle Ages to the Romantic Revival', PMLA 30 (1915), 164-5.

13 Matthew Dimmock, New Turks: Dramatizing Islam and the Ottomans in Early Modern England (Aldershot, 2005), 169.

14 Richard Hillman, "Not Amurath and Amurath Succeeds”: Playing Doubles in Shakespeare's Henriad, English Literary Renaissance 21 (1991), 161-89.

15 William Shakespeare, King Henry IV, Part 2, ed. A. R. Humphreys (Walton-onThames, 1966), 5.2.47-9.

16 The $O E D$ dates the earliest use of the verb 'sham' to 1677 , citing a quotation from William Wycherley's play The Plain Dealer, and to date I have not managed to find another early modern example of the word as it is used here.

17 Thomas Heywood's The Four Prentices of London: A Critical Old Spelling Edition ed. Mary Ann Weber Gasior (New York, 1980), 2.

18 R.A. Foakes (ed.), Henslowe's Diary, 2nd edn (Cambridge, 2002), 17, 22-5, 28, 31.

19 Gasior, The Four Prentices of London, xii-xiii.

20 Ibid, xiii-xv.

21 S. Mendyk, 'Carew, Richard (1555-1620)', Oxford Dictionary of National Biography (Oxford 2004), <http://www.oxforddnb.com/view/article/4635>, accessed $20 \mathrm{Au}$ gust, 2009.

22 A.C. Hamilton, The Spenser Encyclopedia (Toronto, 1990), 678-80.

23 L.G. Kelly, 'Fairfax, Edward (1568?-1632x5?)', Oxford Dictionary of National Biography (Oxford 2004) <http://www.oxforddnb.com/view/article/9080> accessed 20 August, 2009. 
24 Roslyn L. Knutson, Playing Companies and Commerce in Shakespeare's Time (Cambridge, 2001), 57-9.

25 Ibid, 59-61.

26 'Godfrey of Bouillon', Encyclopaedia Britannica, 2009.

27 Richard Lloyd, A Brief discourse of ... The Nine Worthies (London, 1584), sig. G1v.

28 See Mark Thornton Burnett, 'Marlovian Imitation and Interpretation in Heywood's The Four Prentices of London', Cahiers Élisabéthains 32 (1987), 75-8.

29 Thomas Heywood, The Four Prentices of London: A Critical, Old-Spelling Edition, ed. Mary Gaisor (New York, 1980), 11. 2261-7. All further quotations from the play will be taken from this edition and reference will be given in the text.

30 Algernon Charles Swinburne, Age of Shakespeare (London, 1908), 222-3.

31 Arthur Melville Clark, Thomas Heywood: Playwright and Miscellenist (Oxford, 1931), 210.

32 Frederick S. Boas, Thomas Heywood (New York, 1975), 26.

33 Matar, Turks, Moors, and Englishmen, 142-3.

34 G.K. Hunter, 'The Emergence of the University Wits: Early Tragedy', in English Drama 1586-1642: The Age of Shakespeare (Oxford, 1997), 49.

\section{'Now will I be a Turke': Performing Ottoman Identity in Thomas Goffe's The Courageous Turk}

In the past several years, scholars have devoted increasing attention to representations of the Near East and of Persian, Moorish, or Turkish characters in early modern English drama. Many of these studies have examined the cultural, political, and economic encounters between the English and Islamic or quasi-Islamic others, and the ways in which early modern English writers constituted their own identity through representations of the other. In particular, critics such as Daniel Vitkus have focused on the permeability of the boundaries between the ideological constructs of East and West, and the hybrid identity assumed by Englishmen who ventured into what he calls the 'multicultural Mediterranean'. Thus, English identity was constituted not only in antithetical contrast to Near Eastern cultures, but also by the possibility of assimilation into those cultures — of 'turning Turk'.

But what happens when playwrights attempt to reverse this perspective, when the world of the play itself — its setting and most of its characters — turns Turk? Several early modern English plays center around Turkish 